\title{
The process of selecting factors that predict executive remuneration
}

\author{
I.B. Hipkin \\ 3 Hill Drive, Lutterworth, LE 174 BJ, United Kingdom
}

Received January 1992, accepted January 1993

\begin{abstract}
In this article I seek to determine those organizational and individual factors which best predict executive remuneration. I describe how a pilot study was used to test a variety of factors and to eliminate those which were clearly poor predictors of executive remuneration. Applying multiple regression analysis to the data submitted to an executive salary survey, two sets of factors were obtained. Certain factors individually proved to be better predictors, but it was found that a combination of factors yielded the highest coefficients of determination. The weighting of each factor was then determined in order to derive a market pricing model for executive remuneration.

In hierdie artikel poog ek om die organisatoriese en individuele faktore te bepaal wat die vergoeding van uitvoerende beamptes die beste kan voorspel. 'n Loodstudie is gebruik om 'n verskeidenheid faktore te toets en deur die toepassing van veelvoudige regressie-analises op salarisopname-inligting van uitvoerende amptenare, is twee stelle faktore geidentifiseer. Daar is vasgestel dat sekere faktore beter voorspellers is, maar dat 'n kombinasie faktore die beste bepalingskoeffisiënt verskaf. Die gewig wat elke faktor dra, is bepaal om 'n markprysmodel vir die vergoeding van uitvoerende amptenare daar te stel.
\end{abstract}

\section{Introduction}

The method of determining executive remuneration and benefits differs from that of assessing salaries of lower levels within the organization. The salary and benefits data presented in salary surveys for the latter are applicable to organizations whose size and structure may differ significantly. A survey of executive remuneration should present salary and benefits findings according to a wide possible variety of organizational and individual factors that take organizational size and structure into account. With this article I seek to outline how such factors may be selected, how their relative importance may be ascertained, and how they may be used as the basis of an executive salary survey. A limitation of this study is that its purpose was to establish a set of factors for use in a salary survey: although the database was large, it was not practical to test all the many variables suggested in the literature.

The rationale for selecting factors that predict executive remuneration in various salary universes is acknowledged in the literature. In this article the process for selecting, testing and weighting those factors which will best predict executive remuneration are discussed. The weightings of two periods are compared in order to assess how robust the factors are as market conditions change. I then describe how the final selection of correctly weighted factors can be used to develop a market pricing model for determining executive

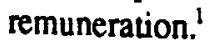

\section{Need for determining factors as the basis of a market pricing model}

The essential difference in using market salaries to determine remuneration levels for executives and non-executives is that the salaries of the latter may be compared to the 'going rate' in the market, which is largely independent of the size and structure of the organizations with which the comparisons are made. This is not the case with executives. The study by Kostiuk (1990: 90) poses the fundamental questions as to what determines the level of executive incomes and what is the sensitivity of these levels to the performance of executives. The answer lies in the extent to which organizational size and an executive's contribution to shareholders' interests are linked to executive pay (Main, 1991). Authors such as Mahoney (1979), and Jackson, Schuler \& Rivero (1989) identify industry sector as another factor affecting executive pay as individual industries are constrained by comparable technology, raw materials, economic cycles, and so on.

It is generally accepted in the literature that the larger the firm (measured in a variety of ways), the higher will be the incomes of the executives employed therein. ${ }^{2}$ This is known as the managerialist explanation of executive pay. The size of organization can be measured in various ways, as will be seen later. The importance of firm size implies that a job evaluated survey of executive remuneration is only meaningful as a basis of comparison between different organizations if it takes organizational parameters into account.

Of the main systems of job evaluation proposed by Ellig (1983: 47), the ranking, classification and point-factor methods fail when applied to executives because they generally neglect to incorporate those factors which pertain to inter-organizational comparison: firm size and structure. One approach that does incorporate such factors is the market pricing philosophy.

Market pricing begins by taking market salary levels, and then seeks commonalities between positions in the same salary universes. Milkovich \& Newman (1984: 257) explain market pricing as determining job worth and executive pay by reliance on the extemal market. Within a given salary universe, the market pricing approach isolates the most important factors common to jobs. The positions within each universe are characterized by such factors, which, as directly related to the market, result in a shift in emphasis from determining the relative worth of jobs on factors intrinsic to the job, to market related factors.

\section{Factors predicting executlve remuneration}

Factors commonly listed as being predictors of executive remuneration include: company sales, assets, profits, stockholders' equity, number of employees, age and length of service of incumbent (Ellig, 1983). To these could be added 
many others, such as: industry sector, salary and wage bill, type of firm (in the sense of holding or subsidiary company), contribution to shareholder interests, and so on. Several of these are more commonly encountered than others, although the reasons therefor are varied. Kostiuk (1990: 95) has found age of executive to be 'irrelevant, although experience as CEO is significant'. Ellig (1983) believes that sales or turnover is the most common independent variable used in compensation regression analysis studies. For this reason more than any other, it usually has the highest correlation with executive pay. Less recent, but widely supported research by Roberts, concludes more narrowly:

'(the pay of a top executive) is related to the size of the company and to virtually no other variables (in particular, not to profit) ... size of company being measured by sales turnover' (1959: 39).

The literature also recognizes that a combination of factors may provide a more accurate prediction of executive remuneration. Kostiuk (1990: 98) states: 'It does seem to indicate that the factors affecting compensation interact in some complex way.' Burgess (1981: 290) alludes to this when providing evidence that a prediction equation using a combination of variables, including sales, can predict executive pay data more accurately than sales alone. As a further example, the American Consultancy Management Compensation Services (Rock [ed.], 1984: 41, 47) use the following organizational size factors: sales (turnover), assets and number of employees; the performance measures are: one year retum on sales, assets and capital. This effectively means that organizational size may be measured in absolute terms (sales, profits, assets, etc) or in relative terms (return on investment, return on equity, and so on).

Several authors, such as Lazear \& Rosen (1981), Bull, Schotter \& Weigelt (1987), question whether executive pay is related to individual productivity. Others, such as Main (1991), Cosh \& Hughes (1987), provide evidence that executive pay is closely allied to normal (level of performance related to the market) and abnormal (level of performance over and above the reference level) increases in shareholder's wealth, as well as the number of executive and nonexecutive directors.

The relationship between pay and performance is considered by many authors, although their mindings are by no means congruent. A broad summary of findings may take the form of the observation by Jensen \& Zimmerman (1985: 20) that 'compensation packages of the top level help align managers' and shareholders' interests'. Other authors, while not disputing this general tenet, are rather more demanding: Tosi \& Gomez-Mejia have found that:

'... executives appear to have the best of both worlds. Their basic salaries were functions of firms' size, a relatively stable factor, their long-term incomes were greater when performance was good and the scale of their organizations provided a downside hedge against poor performance' (1989: 170).

Gomez-Mejia, Tosi \& Hinkin (1987) postulate that ownership is an important factor in predicting executive pay: in firms with dominant external shareholdings, performance is a significant predictor of executive remuneration; where control lies with management of a firm, size and not per. formance predicts pay.

Another factor that may unduly promote remuneration which is not based on performance is that of specifying dif. ferentials between management levels, as proposed by Simon (1957) and Mahoney (1979). With this article I acknowledge that differentials may explain an element of the variation in executive pay, but I do not pursue the matter.

In this study I seek to consider further the nature of the prediction equation, referred to by several authors. Various forms of this equation are found in the literature. For example, Foster (in Rock [ed.] , 1984) gives the following:

\section{log pay (basic salary or total compensation) \\ $=0.1125 \times \log$ of corporate sales \\ $+0.0005 \times$ return on shareholder equity \\ $+0.0683 \times$ evaluation points \\ +10.253 (constant)}

(No dètails are given of the evaluation points.)

A further equation is given by Cosh (1975):

$\log$ cash remuneration $=a_{0}+a_{1} R+a_{2} A+e$ where $R$ is the firm rate of return on assets and $A$ is net assets.

The regression equation used in this study will be considered once the factors have been selected.

\section{Intial selection of factors}

In this section I describe how a series of factors to predict executive remuneration was tested. The first stage in the selection of factors involved undertaking a pilot study: a sample of participants in a salary survey was taken as the basis for further investigation. The sample consisted of 470 executives employed in 56 organizations, in five different industries. The basic salary, total salary (inclusive of all cash remuneration) and total employment cost (inclusive of all benefits, but excluding deferred compensation and stock options) were collected for each individual. Other details on individuals and their organizations were also obtained in order to assess which factors would best predict the executives' incomes. The factors tested in the pilot study were selected as they have been studied, to a lesser or greater extent in the literature. Where it was considered that it would be difficult to gather or quantify data relating to certain factors, these were not tested. One such factor is contribution to shareholder equity. The nature of the sample and the salary survey database would not permit the collec. tion of reliable data for this factor.

The initial factors were divided into three categories. The first category (relating to organizational size) consisted of the following:

- number of employees

- annual turnover (sales)

- value of tangible assets

- annual salary and wage bill

- industry sector. 
The second category of factors (reflecting organizational performance) contained the following:

- annual net profit before tax

- retum on investment.

The third category (assessing individual factors) included the following:

- level of decision making

- consequence of error

- age of executive

- length of service

- organizational level (meaning position, such as CEO, in a

holding or subsidiary company).

In order to enable statistical analyses to be performed, it was necessary to assign quantifiable values to the above factors. For the size and performance parameters, a value can be attached appropriately. In the case of descriptive factors, executives were required to score themselves according to a series of definitions and scoring instructions. All factors were initially weighted equally. (It will be seen that the weightings obtained from the regression analyses conducted in 1984 are retained because subsequent analysis yields little change in weightings.)

\section{Preliminary data stratification}

Points were assigned to the three sets of factors as described above. During the pilot study, the salary and benefits levels for the 470 executives were gathered together with the information pertaining to the factors listed in the three categories.

Because of the relatively small number of individuals in the pilot study, some normalization of the data was necessary. The frequently encountered survey ratio was used to ensure meaningful stratification of the data. A survey ratio of 1.5 was selected, that is, the ratio of the highest to lowest salary in each size category was calculated. The interpretation is that, for example, in the category level Annual Turnover (Sales) R100-R300 million, the highest salary may be no more than 1.5 times the lowest salary. The use of the survey ratio meant that excessively high or low salaries, relative to the data as a whole, were excluded from the analysis.

A measure of capital/labor intensity has also proved useful in data normalization because there may be a significant difference between the remuneration of executives in highly capital industries and labour intensive industries (Kostiuk, 1990: 94). Data were excluded if the ratio of value of tangible assets (the measure of capital intensity) to number of employees lay outside the range R10 000 to R100 000 per employee.

\section{Preliminary assessment of factors}

The significant trend towards the 'cafeteria' approach in the remuneration of senior staff has entrenched concepts such as value of remuneration package or total employment cost as the most meaningful measure of executive remuneration. For this reason, the factors which best predicted total employment cost were sought. Excluded from the total employment cost are deferred compensation and stock options, despite the fact that these can constitute a significant proportion of an executive's income. ${ }^{3}$
Using regression analyses, the coefficient of determination (r-squared) was used to assess the extent to which the variation in the dependent variable (in this case, salary in the form of total employment cost) is explained by the independent variable (in this case, each of the factors being tested). The value of r-squared may be interpreted as follows: when considering the independent variable, say, annual salary and wage bill, and the dependent variable total employment cost for a CEO in a particular industry, regression analysis may yield a value of r-squared of 0.69 ; this means that $69 \%$ of the variation in the total employment cost of that CEO is explained by the variable annual salary and wage bill.

The results obtained from the preliminary regression analyses of all the factors investigated in the pilot study yielded widely varying results for $\mathrm{r}$-squared. The variable with the lowest value of $r$-squared (less than 0.01 ) was the age of the executive. In simple terms, of all the factors considered, age is the least significant predictor of executive remuneration. This finding agrees with that of Kostiuk (1990). The highest value of r-squared (0.90) was obtained for the independent variable annual turnover (sales). Using these values of r-squared, it was decided that certain factors could be excluded as they were poor predictors of executive remuneration.

Multiple regression analyses also indicate which combinations of independent variables will best predict the dependent variable. Such combinations generally produce a higher value for r-squared than individual factors. The factors chosen were those which yielded the highest $r$ squared on an individual basis, using the t-statistic at a 95\% confidence level and infinite degrees of freedom.

Two combinations of independent variables which best predicted the dependent variable were selected: Group 1 considered only directly quantifiable measures of organizational size and performance, while Group 2 combined size parameters with certain individual factors. The two combinations were:

\begin{tabular}{|c|c|}
\hline $\begin{array}{l}\text { Group } 1 \text { - Organizational } \\
\text { size and performance factors }\end{array}$ & $\begin{array}{l}\text { Group } 2 \text { - Stre, performance } \\
\text { and Individual factors }\end{array}$ \\
\hline Toual number of employees & Level of decision making \\
\hline Amnual tumover (sales) & Orgenizational level \\
\hline Amual profit & Annual tumover (sales) \\
\hline Value of ungible assets & Annual salary and wage bill \\
\hline Annual salary and wage bill & Consequence of error \\
\hline
\end{tabular}

The next step was to test these factors in a larger sample. and to establish the correct weighting for each.

\section{Determination of factor weightings}

In 1984 and 1988 participants in a South African executive survey of salaries and benefits were asked to score or rate themselves using a set of explicitly defined rules, also submitting the size and performance parameters of their organizations. Salary and benefits data collected in the salary survey were also submitted by this same sample of nearly 6000 executives in over 1200 organizations in nine different industry sectors. The executive positions extended 
Table 1 Significance of single and combined factors as predictors of total employment cost

\begin{tabular}{llcccc}
\hline \multicolumn{1}{c}{ Factors } & \multicolumn{3}{c}{ Positions } \\
\hline Group 1 - Company size and & \multicolumn{2}{c}{$\begin{array}{c}1984 \\
\text { CEO }\end{array}$} & $\begin{array}{c}\text { Marketing } \\
\text { executive }\end{array}$ & & $\begin{array}{c}\text { CEO } \\
\text { Marketing } \\
\text { executive }\end{array}$ \\
\hline Number of employees & & 0.66 & 0.63 & 0.66 & 0.65 \\
Annual tumover & 0.91 & 0.77 & 0.92 & 0.79 \\
Annual profit & 0.56 & 0.41 & 0.50 & 0.36 \\
Value of tangible assets & 0.67 & 0.65 & 0.66 & 0.65 \\
Annual salary and wage bill & 0.70 & 0.62 & 0.72 & 0.62 \\
\hline All Group 1 factors combined & 0.92 & 0.85 & 0.93 & 0.87 \\
\hline Group 2 - Company and individual factors & & & & \\
\hline Level of decision making & & & & 0.65 & 0.63 \\
Organization level & 0.64 & 0.63 & 0.79 & 0.75 \\
Annual tumover & 0.80 & 0.74 & 0.92 & 0.79 \\
Annual salary and wage bill & 0.91 & 0.77 & 0.72 & 0.62 \\
Consequence of error & 0.70 & 0.62 & 0.63 & 0.60 \\
\hline All Group 2 factors combined & 0.65 & 0.61 & 0.63 & 0.87 \\
\hline
\end{tabular}

from CEO to other executives, such as Financial and Human Resource executives, in both holding and subsidiary companies.

One immediate problem in the exercise so far was that all factors were weighted equally. This is unsatisfactory because, as Sargent points out:

'Experience has shown that except by rare coincidence each factor carries a different force (or weight) in determining job content. Consequently, each factor has a different point value' (in Rock [ed.], 1984: 11/ 4).

An assessment was made of how well the various factors predicted executives' basic salary, total cash salary and total employment cost, by comparing the results of a series of regression analyses. Given in Table 1 are the results for the CEO and Marketing Executive positions, of the single and combined values of $r$-squared for the two groups of factors mentioned above. The regression exercise was repeated in 1988. Figures are shown for 1984 and 1988 (see Table 1).

In Table 1, the r-squared figure for the All Group 2 Factors Combined has been assigned a value of 1.00 , with other factors expressed as a proportion of this figure.

It is evident from the r-squared values in Table 1 that the best single predictor is annual company turnover (sales), and that the poorest predictor is annual company profit (corroborating the views of Roberts and others). Both sets of factors (for each year) chosen show that the combinations of factors yield a higher value of $r$-squared, thereby indicating that the combinations of factors are better predictors of executive remuneration than any of the single factors alone.

It is also apparent that the factor combinations are better predictors of the CEO's remuneration than that of the Marketing Executive. It may therefore be suggested that a different set of factors should be used for each executive position. However, from a practical point of view, it would be cumbersome to assign different sets of factors (with different weightings) to each executive position. In order to obtain the best overall picture for all executives in the sample, a series of regression analyses was conducted for the entire sample. The correct weighting for each factor was obtained from the regression coefficients: these are the $\beta$ coefficients in the regression equation of the form:

$\log$ remuneration $=\alpha+\beta_{1} x_{1}+\beta_{2} x_{2}+\beta_{3} x_{3}+\ldots$

Assigning a weighting value of 1.00 to annual turnover, the weightings shown in Table 2 were obtained.

It can be seen from Tables 1 and 2 that there is little change in the relative importance of the factors when comparing the figures for 1984 and 1988. As a factor on its own, profit is seen to be less important in 1988 than in 1984. It remains the least significant predictor of remuneration by a considerable margin, as is evident from Table 1 . The regression coefficients in Table 2 also show a reduced figure for profit. Other figures have not changed significantly.

The results do not at this stage include industry sector, although it is felt that this is an important variable whose list effects should be analyzed. The reason is that industry sector classifications collected for executives in holding companies did not take into account that subsidiaries of the holding companies could be in several categories. This inconsistency would partially explain the spurious industry sector results.

\section{Market pricing model}

Since the Group 2 factors give a better overall prediction of executive remuneration, these factors were selected as the basis of the market pricing model. The initial factors in Group 2 may now be re-weighted in order to incorporate the 
Table 2 Regression coefficient values

\begin{tabular}{llll}
\hline & & 1984 & 1988 \\
\hline Group 1 & Number of employees & 0.65 & 0.66 \\
& Annual tumover & 1.00 & 1.00 \\
& Annual profit & 0.40 & 0.37 \\
& Value of tangible assets & 0.62 & 0.60 \\
& Annual salary and wage bill & 0.56 & 0.58 \\
\hline Group 2 & Level of decision making & 0.79 & 0.79 \\
& Organization level & 1.08 & 1.06 \\
& Annual tumover & 1.00 & 1.00 \\
& Annual salary and wage bill & 0.56 & 0.60 \\
& Consequence of error & 0.67 & 0.66 \\
\hline
\end{tabular}

Table 3 Point values for Group 2 factors

\begin{tabular}{|c|c|}
\hline Factor & Point range \\
\hline Level of decision making & $1618212428-$ \\
\hline Organization level & $22263239--$ \\
\hline Annual tumover & 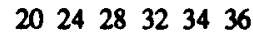 \\
\hline Annual salary and wage bill & $\begin{array}{llllll}11 & 13 & 16 & 18 & 19 & 20\end{array}$ \\
\hline Consequence of error & $1315182124-$ \\
\hline
\end{tabular}

results of the regression analyses. The point values for each of the Group 2 factors are thus given in Table 3.

The market pricing model is thus developed by having executives score themselves, and then using the market pricing survey data to establish their market related remuneration levels. The Group factors and their definitions remain the same, except that the weightings of the factors then become those given in Table 3. Although regression analyses were conducted on the data for two distinct years, only one set of weightings is used: it was felt that the barely perceptible changes in relative importance of the factors from 1984 to 1988 do not justify a change in weightings.

As an example, assume that a CEO is employed in an organization with the following size parameters, and where the CEO's level of decision making, organization level and consequence of error are as shown in this example:

Level of decision making

Responsible to shareholders only for all policy decisions Score 28

Organization level

CEO Holding company

Score 39

Annual turnover

R46 million

Score 28

Salary and wage bill

R28 million

Score 18

Consequence of error

Errors will affect survival of company, but will only become apparent some years

Score 24

Total score 137

(Space does not permit the inclusion of the scoring definitions and rules whereby the above scores are determined.)

The executive now needs to relate this score for a CEO to the market value of remuneration, which would typically be supplied by the remuneration survey as shown in Table 4 .

The CEO with a score of 137 will thus expect to earn between R207 000 (lower quartile) and R312 000 (upper quartile) per annum. The percentile chosen will depend on a number of factors such as company policy, as well as the fact that 137 is the maximum in that category: it would be expected that the executive would be paid towards the upper quartile.

Three reasons for discrepancies between predicted executive pay and actual pay are given by Main (1991): some companies are more aggressive in tying top executive pay to company performance (such as profit); the volatility of the market; evidence of top executive pay lagging behind company performance.

\section{Conclusion}

In this article I have described how factors were chosen that would best predict executive remuneration, using multiple regression analysis. The better combination of factors (with factor weightings also determined by the regression analysis) was then used to develop a market pricing model which takes into account organizational size and performance factors as well as certain organizational factors. The model relies on an individual's scoring the executive position using a set of rules. The process is subject to the same criticism that could be levelled at any job evaluation system (inexactitude of the factor definitions, subsequent misinterpretations and possible inaccurate scoring of individuals' positions). This study has analyzed the data at two specific points in time: the factors and weightings seem to exhibit a robust set of circumstances. After a further time period, additional work considering the changing importance of factors over a number of years may provide an interesting extension to the study.

The important outcome of a study such as this is that a simple model is produced which considers both organizational size and performance, as well as individual factors, when seeking a basis for determining market related executive remuneration.

Table 4 Typical presentation of market salary data by point score

\begin{tabular}{|c|c|c|c|}
\hline \multicolumn{4}{|c|}{$\begin{array}{l}\text { Chief executive officer } \\
\text { All industry sectors combined }\end{array}$} \\
\hline \multirow[t]{2}{*}{ Point score } & \multicolumn{3}{|c|}{ Remuneration (Total employment cost) } \\
\hline & Lower quartile & Median & Upper quartile \\
\hline $82-88$ & \multicolumn{3}{|c|}{ no data available for CEO } \\
\hline $89-95$ & \multicolumn{3}{|c|}{ no data available for CEO } \\
\hline $96-102$ & \multicolumn{3}{|c|}{ no data available for CEO } \\
\hline $103-110$ & $\mathrm{R} 137000$ & R155 000 & $\mathbf{R} 173000$ \\
\hline $111-118$ & R155 000 & R183000 & R207000 \\
\hline $119-127$ & $R 176000$ & R217 000 & $\mathrm{R} 249000$ \\
\hline 128-137 & $\mathbf{R} 207000$ & R268 000 & $\mathrm{R} 312000$ \\
\hline $138-147$ & $\mathrm{R} 242000$ & R331000 & R392 000 \\
\hline
\end{tabular}




\section{Notes}

1. The remuneration survey database used in this study was that of P-E Corporate Services (Pty) Limited. I acknowledge the use of this database.

2. See, for example, Roberts (1959), Crystal (1989), Cosh (1975), Kerr \& Bettis (1987), Kostiuk (1990), Oi (1983).

3. Different authors have varying approaches to the measure of remuneration in comparable studies. Kostiuk's (1990) study concentrated on total cash remuneration and also excluded deferred compensation and stock options. Gerhart \& Milkovich (1990) found that contingent pay is associated with financial performance, but basic pay is not. This study follows Kostiuk as both contingent and basic pay are included in total cash remuneration.

\section{Roterences}

Bull, C., Schotter, A. \& Weigelt, K. 1987. 'Toumaments and piece rates: an experimental study', Journal of Political Economy, Vol. 95, No. 1: 1-33.

Burgess, L.R. 1981. Wage and salary administration. Columbus: Charles E. Merrill, 434p.

Cosh, A. 1975. 'The remuneration of chief executives in the United Kingdom', Economic Journal, Vol. 85, No. 1: 75-94.

Cosh, A.D. \& Hughes, A. 1987. 'The anatomy of corporate control: directors, shareholders and executive remuneration in giant US and UK corporations'. Cambridge Journal of Economics, Vol. 11: 285-313.

Crystal. G.S. 1989. 'Seeking the sense in CEO pay'. Compensation and Benefuts Review, Vol. 21. No. 5: 65-69.

Ellig. B.R. 1983. Executive compensation - a total pay perspective. New York: McGraw-Hill, 343p.

Gerhar, B. \& Milkovich, G.T. 1990. 'Organizational differences in managerial compensation and financial performance', Academy of Management Journal, Vol. 33, No. 4: 663-691.

Gomez-Mejia, L.R., Tosi, H. \& Hinkin, T. 1987. 'Managerial control, performance, and executive compensation', Academy of Managemens Journal, Vol. 30, No. 1: 51-70.

Jackson, S.E., Schuler, R.S. \& Rivero, J.C. 1989. 'Organizational characteristics as predictors of personnel practices'.

Jensen, M.C. \& Zimmerman, J.L. 1985. 'Managerial compensation and the managerial labor market'. Journal of Accounding and Economics, April 1985, 3-9.

Kerr, J. \& Bettis, R.A. 1987. 'Boards of directors, top manage ment compensation and shareholder returns', Academy of Management Journal, Vol. 30, No. 4: 645-664.

Kostiuk, P.F. 1990. 'Firm size and executive compensation'. The Journal of Human Resources, Vol. 25. No. 1: 90-105.

Lazear, E.P. \& Rosen, S. 1981. 'Rank-order tournaments as optimum labour contracts', Journal of Political Economy, Vol. 85, No. 5: 841-864.

Mahoney. T.A. 1979. Compensation and reward perspectives. Homewood Ill.: Richard D. Unwin, 312p.

Mahoney, T.A. 1979. 'Organization hierarchy and position worth'. Academy of Management Journal, Vol. 22: 726-737.

Main, B.G.M. 1991. 'Top executive pay and performance', Managerial and Decision Economisc, Vol. 12, No. 3: 219-229.

Milkovich, G.T. \& Newman, J.M. 1984. Compensation. Plano: Business Publications, 548p.

$\mathrm{Oi}, \mathrm{W} .1983$. 'Heterogeneous firms and the organization of production', Economic Inquiry, Vol. 21, No. 2: 147-171.

P.E Corporate Services (Pty) Limited. 1984, 1988. Top execulive salary surveys. Johannesburg: P-E Corporate Services.

Roberts, D.C. 1959. Executive compensation. Illinois: Free Press, 283p.

Rock, M.L. (ed.). 1984. Handbook of salary and wage administration. New York: McGraw-Hill, 642p.

Simon, H.A. 1957. 'Compensation of executives'. Sociometry, Vol. 20: 32-35.

Tosi, H.L. \& Gomez-Mejia, L.R. 1989. 'The decoupling of CEO pay and performance: an agency theory perspective', Administrative Science Quarterly, Vol. 34: 169-189. 